

\title{
Exploring the Influences of Political Branding: A case from the Youth in India
}

\begin{tabular}{|r|l|}
\hline Journal: & Journal of Indian Business Research \\
\hline Manuscript ID & JIBR-12-2016-0142.R2 \\
\hline Manuscript Type: & Research Paper \\
\hline Keywords: & Political Branding, Influences, India \\
\hline \multicolumn{3}{c}{$\begin{array}{r}\text { SCHOLARONE } \\
\text { Manuscripts }\end{array}$} \\
\hline
\end{tabular}




\section{Exploring the Influences of Political Branding: A case from the Youth in India}

\section{Introduction}

Every successive election's political campaign has been characterized by renewed marketing and communication tools. These tools solidify the bond between the candidate and the voter (Cogburn and Espinoza-Vasquez, 2011). This prevalence can influence the field of politics. Specifically, the credit for this prevalence is given to political branding (Yan 2001). These platforms offer a convergence of tactics which becomes a part of politics (Chadwik and Howard, 2009).

This convergence also maximizes the interaction between parties and voters (Cogburn et al. 2011). Further, it is very difficult to marshal supporters and gain the support of prospective voters (Stanyer, 2005). If these requirements are perfectly aligned with the performance of the political party, it can lead to modes of engagement. Further, a strong political brand is a heuristic for both the market orientation (Lees Marshment, 2001) and political orientation (O’Cass and Voola, 2011) that define a political party.

A strong political brand also synchronizes the three focal points of these two orientations: political information, interest and attention (Bartle and Griffith, 2001). These focal points are extremely important because they can be synchronized "to reduce the complexity in an environment of proliferating choice and information" (Needham 2006, p.184). Thus, brands help the voters' connect with the political brand at a functional and emotional level.

In line with this, key studies have focused on both aspects of the connection (Pich et al. 2014). These aspects gain urgency in the eastern context especially, China, Vietnam, Malyasia and India. This is because, these countries, especially India, enjoy a high demographic dividend. 
Experts have noted that there are similar patterns in campaigning strategies including consideration of voters as consumers (Baines et al. 2005). Thus, political branding can be better understood in the non-western contexts. This is particularly so when the postelection scenario is taken into consideration. The reason for considering the post-election scenario is that most political parties and leaders focus on election and pre-election campaigns. This creates a gap in the connection between the political leaders, parties and the voters. This issue will be addressed by our study. By addressing this issue, we will understand the influences of political branding.

The insights developed can be used to strengthen their relations with the voters. This relationship is enhanced further by the political parties by two means. The first means is youth mobilization for politics. The second is extensive use of social media by social parties. (Bhatia, 2017). However, there are limited studies on political branding in the post-election context (Fernandez Vasquez, 2014). Neither have there been studies on the development of a reciprocal and embedded relationship based on political branding. A few studies that have attempted to address this issue have discovered the importance of the perception and association of the leader with the leader with the voters (Jain et al. 2017).

Further, the political brand image is dependent on exemplification, self promotion and humility of the politician and the party (Jain et al. 2017 Forthcoming). Additionally, political campaigns have a positive effect on the party and the leader. This positive effect often makes voters ignore the factual information about the party and the voter (Banerjee \& Choudhary, 2016) Primarily, these studies focus on the Indian voters and the political parties. Despite this, the focus of existing political branding scholars has been on traditional voters of an older demographic set. 
Therefore, the current research will significantly contribute to the post-election scenario focusing on new and emerging voters. Further, these studies will develop a theoretical frame work that might support practitioners in developing approaches and strategies for political parties and leaders. The subsequent literature review will focus on political branding, young voters and existing theories.

Further, the present study would also extend the understanding of the branding literature as political branding focuses on the symbolic dimensions and ideologies of the political leaders and parties. This dimension closely co-exists with the functional dimension of the political brand. Thus, political branding is similar to yet different from product and services branding.

\section{Literature Review}

The following sections will encapsulate the findings of key studies in political branding, political branding and youth and theoretical frameworks. The key studies have been conducted in developed nations. This is because there is a concordant dearth of studies and literature in the non-western contexts.

Thus, we have used the studies as a base to develop relevant domains. Further, we have carried out an exploratory study to develop non-western perspectives from the theories and insights used. We have also ensured that the findings are not directly replicated. Also, we have also ensured that the findings based on the extant political branding literature have not been applied directly without exploration.

This exploration has been conducted commencing from the respondent data collection, analysis, themes and frame development. This has ensured that the ideas and construct developed in our study is novel to India. Yet, they can be expanded and explored in the contexts of other countries. 


\subsection{Political Branding}

Political branding is the strategic use of consumer branding tactics in the building of a political image (Nielsen, 2016). There have also been perspectives that politics can be contextualized as a service with three components. First, policy as the service offering; second, the politician as the tangible service offering; third, the party as the brand offering (Henneberg and O'Shaughnessy, 2007).

Therefore, existing research has focused on the political candidate brand (Guzman et al 2014), and Obama's communication strategy (Miller 2014). Studies have focused on political campaigns (Casteltrione, 2015), the development of new political brands (Busby and Cronshaw, 2015) and political brand image (Pich and Armannsdottir, 2015).Thus, the process of political branding involves the development of symbols and shared values that can be associated with the political parties and candidates (O'Shaugnessy et al. 2012).

Political branding platforms have reached a point characterized by instantaneous connections, rapid networking and viral impact (Fraser and Dutta, 2009).The characteristics of this phenomenon are that they enable the contraction of time and expansion of interactive space. Such a brand building exercise will need both control and credibility (Milewicz and Milewicz, 2014) simultaneously.

This can be achieved by maximizing the potential of voters to verify the content of the party's branding exercise. Thus, political branding platforms should incorporate the above attributes to develop a strong base of credibility (Dumeresque, 2012). Once these attributes are aligned with a planned political branding exercise, parties can have more iterative and meaningful engagement with voters. This augmented engagement can encourage voters to be channels for the political party and leader. 
Thus, they can help more voters feel that they are connected to the party (Booth et al., 2014). This is crucial when political brands need to attract prospective voters (Moran et al., 2014), primarily young voters that often represent an untapped market (Pich et al. 2014).

\subsection{Political Branding and the Youth}

The young generation is separated from institutions that could guide them about the effective management of political issues (Bennett, 2013). Further, they tend to seek platforms through which they can extensively use and gain comprehensive information with minimal effort (Karpf, 2009).Thus, political branding requires platforms that encourage connective action, rapid opinion formation and dispersal and mobilization (Bennett, 2013; Pich et al. 2014).

This active mode is very necessary as political brands and young voters need to possess an almost symbiotic relation. This action orientation is different from the earlier characteristic of political branding being more of a synchronization of the needs of the voters and the political party.

The issue with this synchronization is that the voters are dialectically separated from the party and designated more as recipients (Campbell, 2013). Political parties need to create embedded relations with the voters on the basis of these normative insights (Delaney, 2009).These insights can be understood by the relevant theoretical frameworks and lead to the comprehension of the influences of political branding. 


\subsection{Influences of political branding and Theoretical Frameworks}

To understand the influence of political branding, this study considered the work of Brake (2015) who conceptualized a framework entitled Borderless Collaboration: Creating value together in the new world of work. Here, we found that there are key functions such as collaboration, media maximization fluid and cross functional team effectiveness needed to function optimally.

Further, these key functions operate in tandem with specific abilities: ability to communicate readiness, ability to be clear, ability to maintain virtual presence and ability to communicate sufficient context. These findings have emerged in the context of leaders functioning in the digital space and taken the form of collaboration, directing combined efforts and processes (Axelrod, 2000).

Thus, a leader in the political space too will be required to integrate certain abilities into all operations including communications. However, this framework was not applied to the political context and theoretical frameworks of politics. Hence, the means to integrate the earlier observations in the political context was the virtuous circle theory of Norris (2000).

It states that greater exposure to media and party communication can create greater awareness and trust of the political system in those tuned to politics. The same are also less likely to be cynical regards elections and electoral participation. This proposition has been positively corroborated in the institutional, individual and organizational contexts and the theory applied to a study of 21 countries with both common and different political systems (Norris, 2000). 
The theory has also demonstrated that there is a strong positive link between democratization and information accrual about politics. These capabilities are imperative for political branding to forge horizontal ties and connections among the following diverse, autonomous elements: the free and open circulation of information, collaboration through decentralized coordination and consensus decision-making, and self-directed networking (Juris, 2004).

The theory and its potential have not been used in tandem with the qualities required for political leaders. This reciprocal structure should restructure political branding formats from a target based activity to participation. This re-contextualization is more effective when it is effected in the post-election space and time frame (Balmas \& Sheafer, 2013).

In the post-election space, political brands should move from being an external element restricted to catering to the voter's requirement. Instead they should become a more embedded element (Holt, 2002).Our study aims to develop the influences that will assist this progression of political branding. This functioning is premised on the MIST format; Mobile, Intimate, Social and Transactional (Eslinger, 2014). This framework is used in mobile marketing.

But, it can apply to this context as the aim is to study the influences of political branding. The MIST framework provides foundational elements for political branding. The reason for each of these foundational elements will be explicated in terms of political branding. Mobility in the context of political branding means the political parties need to have near complete flexibility. 
This flexibility should be related to assessment, decision making and execution of projects and action plans. These plans should be specific to the socio- geographical contexts of the voters. Intimate, in this context, means that the units narrowcast language, symbols and metaphors in a manner that is nearest to the specific socio- political dimensions. The last foundational element, transactional is the ability to optimize the interaction between in process assessment, integration of old and new orders and convergent and divergent paths.

The Social element in this context means maintaining ground level contact with the consumers and voters. Social also means that political parties and leaders need to be constantly in tune with the requirements of the consumers and the voters. Transactional, specifically would benefit when it is supplemented by the advice and collaboration of experts in policy making and politics.

This format needs a solid, comprehensive and highly accepted theory in order to allow it to enrich the field of political branding. This MIST framework is one of the foundations of the explorations of the current study. This is because this framework has facilitated the study in exploring and developing the dimensions of the current study.

In line with this, the second foundation was provided by Norris (2000) who stated that those people positively attuned to political communication will be further attuned by increased exposure to the same. This concept can be used to integrate, coalesce and present MIST format (Eslinger, 2014) and the four qualities stated by Brake (2015).

Finally, by merging the characteristics required of a political party and a leader in terms of branding, this study will provide a framework that accommodates the political party's perspective and leaders' requirement. In order to contextualize the same, we will position the same in the context of an emerging nation; India. 


\subsection{Political Branding in India with the Case of BJP (Bharatiya Janata Party)}

With the rise of regional voting blocs (Hallin and Mancini, 1984), the constitution and direction of political campaigns in India have undergone considerable changes. One of the most important changes witnessed was the incorporation of synchronized political campaigning strategies on behalf of political actors (Negrine, 2008).

The 2014 parliamentary elections in India and the BJP victory in it has been a watershed moment in the country. The BJP came to power in 1998 and had formed the government with the National Democratic Alliance (NDA). In alliance with the NDA, the BJP was able to stay in power till 2004.

In 2014, by projecting Narendra Modi (NM) as the prime ministerial candidate, the BJP had hoped to outdo their 1998 success. The choice of NM as the prime ministerial candidate was a factor that contributed positively to the BJP's objectives. The reason for choosing the BJP and the Indian context is that there have been several studies about political branding (Rawson, 2007; Reeves, Guzman and Sierra, 2009; Pich et al. 2014) in the Western context but limited studies on political branding in the eastern context.

This highlights a shortage of research on political branding in an eastern context. The existing literature on political branding calls for more insight into how the influences of political branding can be utilized in the post-election scenario in the non-western context. The first such scope is the means to optimize the power of engagement between the political party and the voters that goes beyond mobilization, co-production and earlier modalities that were used in branding and political branding thereof. This gap will be elaborated in the further sections. 


\section{Research Gap and Objectives}

There have been studies that have considered the party's and the leader's capacity for positive political mobilization (Hamilton and Tolbert, 2012), and greater political involvement (Baumgartner and Morris, 2010). Yet, almost all these studies do not provide for an active guiding framework that can foster a deeply embedded connection with the voters. Further, our study will offer the influences of political branding.

The reason for this is that earlier studies focus on the placement of characteristics and information (Speed et al. 2015). This explicit focus on information dispersal formats has created a very discernible gap in political branding. This gap is widened as these studies do not focus on the post-election space.

Additionally, these studies are analytical and retrospective without an actionable framework that can be used by political parties to create an embedded relation with the voters. Despite this, few studies have attempted to explore the values and messages communicated to voters especially from an external perspective.

We could identify only a few studies focusing on the importance of the link between the efficacy of political leaders and political marketing (Temple, 2010).An overwhelming number of studies have considered successful election strategies like that of Obama's in 2012, USA, or the British Conservative Party's in 2010 (Delaney, 2009; Lutz, 2009; French and Smith, 2010; Pich et al. 2014).

Even they study political branding as part of the pre-election campaign. In continuation, these studies do not provide the required practical guidelines and influences to strengthen the bonding between the voters and the political parties. 
Further, there is less research in the Indian political context where neither the pre-election political branding nor the post-election political branding has been studied in a systematic manner. Thus, this research aims to study how the BJP connected to the voters and how this was decoded post the 2014 election campaign. This study also identifies how the BJP's long term proactive strategies influence and groom the voters for the next election. Thus, the study addresses the following objectives:

- To understand the influences of political branding from the perspective of external stakeholders, especially, young voters

- To develop a framework focusing on the influences of political branding, which can be used by both practitioners and academics

The following section will deal with the methods and methodology used to develop the same.

\section{Methodology}

The study adopted a qualitative approach to achieve its objectives. Specifically, we followed the precepts of the interpretive approach to ensure that rich and situated data were elicited. Qualitative methods were used because the investigation was oriented towards identifying perceptions and beliefs (Milena et al., 2008). Thus, focus group discussions (FGD) were especially effective as there is a serious lack of empirical and theoretical studies regard the area of study (Yin, 2003).

Further, FGDs also generate insights about collective viewpoints (Sultan et al. 2016). Finally, FGDs may surface information that a survey or other qualitative techniques may not reveal (Cresswell, 2007). This surfacing is made possible by these characteristics of the FGDs: self-disclosure - which refers to personal information and preferences being revealed, substantialness- which refers to answers that give the reasoning behind their response, and breadth -which refers to most parts of the research questions(Kamberelis and Dimitriadis, 2013; Wyatt, Krauskopf and Davidson, 2008). 


\subsection{Sampling}

A total of 17 FGDs with 147 participants were conducted (Refer Table 1). The respondents were recruited through purposive and snowball sampling. The age group of the respondents was 18-30 years because the young voters in India are very active and seek information about political parties and party leaders through various platforms.

In addition, the young voters of India also share this information with their peers and social circles and form opinions based on it. The young voters between the age group of 18-30 in most of the cities possess multiple gadgets to retrieve information about Indian politics and political parties.

This is true of both the working professionals and students represented in this group. The respondents for all the groups were requested to join the FGD after having been provided with clear guidelines. The selection criterion was that they need to have been a resident of their particular city for a minimum time period of 10 years.

All the respondents belonged to the Socio- Economic Class A (SEC A). SECs are defined in accordance with the goods owned by the individuals. This definition is provided by the Indian Marketing Research Society. The interests of the current study required us to focus on SEC A due to the uniformity and affluence of the respondents.

This ensured that they had access to various types of messages delivered by the BJP. Thus, the demographic group of 18-30 year old respondents represented a third of the Indian voting population and shaped the outcome of the 2014 Indian general election (Chouhan, 2014). The respondents were selected from the Indian cites of Delhi, Mumbai, Pune and Hyderabad. 
The reasons for selecting the above mentioned cites are as follows. Delhi is the capital of India with a population of more than 10 million. It has an internet base of 12.15 million.Mumbai is the financial capital of India and boasts of population of over 18 million. It has the highest internet base at about 16.4 million and.Bangalore is the IT hub of India with a nine million population. It has an internet base of 3.8 million. Pune has a 3.1 million population. It has an internet base of 2.7 million.

Hyderabad is a royal city with a population of 6.8 million. Ithas an internet base of 4.7 million. (Indiaonlinepages.com, 2016; Indexmundi.com, 2016); Dazeinfo, 2016; Indian web2, 2016).

\section{Insert Table 1 here}

\subsection{Protocol and Process of Conducting FGDs}

The protocol was developed on the basis of research questions, objectives and the earlier studies conducted in political branding. Here, we extensively the three foundational elements of the MIST framework (2014), Norris' Virtuous Cycle Theory (2000) and the 6 Cs framework of Brake (2015). These elements were extensively used while developing the protocol.

The first stage of the protocol aimed at understanding the overall perception, feelings and beliefs of the voters about the BJP Party, leader, their communication approaches and messages delivered. In the second stage, we focused on developing the influences of political branding.

The third stage of the discussion focused on the overall functioning of the Party and the leader and their subsequent expectations for the next elections. The detailed FGD guide is provided in Appendix 1. 
The FGDs were conducted in comfortable settings such as lecture halls of institutes and conference halls of hotels of the relevant cities. The first author moderated all the FGDs running for an average time span of 1.5 hours each. The medium of discussion was English.

The language is popular among the respondents of the cities chosen. The groups were encouraged to discuss in an unhindered manner ensuring coordinated discussions. The respondents were also encouraged to ask questions whenever they felt the relevance. All the discussions were transcribed from video recordings which helped in their analysis.

\subsection{Analysis}

To understand the perceptions and beliefs, we used three progressive and broad phases: initial design, in course extension and full frame development. Initial design was developed through the interaction of a deductive and inductive rationality (Pettigrew, 1997).

This was used to understand the process of political branding of the BJP among young voters. Similarly, in course extension (Singh, 2015) was developed by selecting, integrating and operationalizing the perspectives of our respondents. Finally, full frame development, i.e. a conceptual framework, was developed by assimilating, integrating and differentiating the data collected from the respondents.

Thus, we created new knowledge by immersing in the contexts of political branding and political brand in India, primarily the BJP. This acted as a deductive framework which guided our data collection and resulted in the elicitation of unique and novel insights from the respondents.

With the support of the virtuous cycle theory (Norris, 2000), the MIST framework proposed by Eslinger (2014) and the qualities proposed by Brake (2015), four key themes were revealed: ability to communicate readiness for quick and relevant actions, ability to be clear in the expression of the leader's strength, ability to maintain virtual presence and ability to communicate performance and results as illustrated by figure 1 . 
We realized that these were the requisites that our respondents had stated. For this, our theoretical base was quite firm. The same needed to be achieved for the corpus of respondent data and our interpretation of the same. In order to achieve this, the FGDs were transcribed and analyzed using Butler-Kisber's (2010) two stage thematic inquiry analytical process.

Data analysis commenced with open coding, which involves the breaking down of data into separate units of analysis. These units are categorized as concepts labeled in accordance with the respondents' words. The next step involved axial coding to achieve a more nuanced level of conceptualization.

The final stage of coding was based on the MIST framework (2014). This usage was extensively supported by the 6Cs framework of Brake (2015) and Norris' Virtuous Cycle Theory (2000). In this direction, the researchers independently developed items and domains (Strauss and Corbin, 1990).

These domains and items were then set in a "continual cycle" (Hennink et al, 2011) of rigorous analysis and comparison till the study synchronized the initial coding with the theoretical concepts and research objectives. Subsequently, information saturation was achieved and the framework was stabilized due to iterations which ensured that replication and theory validation were achieved. After conducting 17 FGDs, this stage was reached.

Then, study finalized the framework that was developed by using the insights of the respondents and theories and framework. Thus, we had to conduct the requisite number of FGDs to capture the relevant sample. This helped maintain a nuanced comprehension of political branding and brand matched by a representative approach.

Insert Fig. 1 here 


\section{Results}

\subsection{Ability to communicate readiness for quick and relevant actions}

\subsubsection{Personalization and connection}

The study brought to the fore the necessity of personalization and connection perceived by the respondents about the BJP and its leader. The respondents confirmed that the leader of the party connects easily with the common person of the country. This is because he addresses himself to current issues.

A respondent, Narayan stated that, "Whenever he speaks, he speaks about the common man. That is why he is listened to when he speaks" (Male, Delhi, 25 yrs). Specifically, the young voters directly associate themselves with the leader as he is in constant touch with this set of citizens. The respondents stated that young voters are interested in the key agenda; a very action oriented one, which the leader has acted upon. Another respondent, Michael, stated that, "Ideally the P.M. should get in touch with the youth. He can connect directly with them with regards to what to do" (Male, Pune, $22 \mathrm{yrs).}$

The respondents stated that the leader needs to communicate and act in accordance with what the youth strongly feel about action oriented agendas. Respondents expressed that the Party uses an idiom and communication style that is similar to their own. Therefore, the study found that the leader and the party have directly communicated with the voters at a personal level. Further, they achieved connection by using a communication pattern similar to theirs and focused key agendas that required quick actions. 


\subsubsection{Mobility in information dispersal}

The respondents perceived that the decisions taken by the party and leader were voter centered when based on their current achievements. They believed that the party and leader were contextually relevant and dynamic as they stated the results that had been accomplished by them. A respondent, Sylvia, stated that, "Most of these updates are about the policy decisions they have made or the actions they have taken. So, you could actually look forward to them" (Female, Bangalore, 23 yrs).

As an extension, the respondents felt that the party is quite trustworthy as it focuses on enhancing the welfare of the country. Thus, a respondent, Ned, stated that "They are kind of communicating it to the mass so as to make the people of the country assured that they are doing something for the welfare of the country" (Male, Mumbai, 26 yrs). However, the respondents offered a cautionary note when they expressed that the party would need to position its messages separately from its ideology. This was very necessary as the party's ideology may not possess a wide scale of congruence.

Thus, a respondent, Gwen, stated that, "The political ideology might not suit everyone. Connection seems to be based on governance" (Female, Hyderabad, $25 \mathrm{yrs}$ ). Therefore, the study found that the leader and the party were found to be trustworthy as they were honest and focused on the nation's welfare. But, they would need to carefully position their communication to ensure that it is not hindered by its ideology. 


\subsubsection{Interactivity with voters and Reciprocity in terms of voter needs}

The study has identified that interactivity and reciprocity are key dimensions. These dimensions should be kept in mind by the party and the leader to portray of a positive brand. Respondents were thrilled when they saw that the platform used by the party and the leaders helped them express their views and ideas. Further, they could also comment on the approaches and strategies used by the leader which would allow him to figure out the views of the people. A respondent, Nalene stated, "Social media allows people to comment. Now common people can comment. The candidates can figure out what the people are saying” (Female, Mumbai, 26 yrs).

Extending from this, respondents felt that reciprocity was achieved easily because the party and the leader had set in place an easy and simple communication channel for the common man. A respondent, Jules, stated that "I feel there is a 2 way communication going on. I can communicate directly with a higher authority without anyone in between" (Male, Delhi, 24 yrs).

An advantage of maintaining high levels of interaction and reciprocity is that it culminates in the dimension of inclusion. A respondent, Madson stated, "You sort of feel included in the thing when you know what it is about" (Male, Pune, 23 yrs).

In summary, the study found that interactivity, reciprocity and inclusion facilitated the development of political branding of the party and the leader in the minds of the voters. This was possible because the respondents were able to freely express their views and communicate directly with the party and the leader. Thus, the research proposition can be put forward after integrating all the themes: 
P1: Personalization, mobility and interactivity constitute the check point of the ability to communicate readiness for developing strong political branding

4.2 Ability to be clear in the expression of the leader's strength 4.2.1 Leader superimposing on the party

The study elicited observations regarding the ubiquity and overarching image of the party leader. Respondents stated that they found the leader to be with a strong presence which is nearly impossible to ignore or not reckon with. A respondent, Denise, stated, "Whether you like him or hate him, you can't ignore him. He's in your face. You will see it irrespectively"'(Female, Pune, 24 yrs). This overarching presence of the party leader could be a strong dimension aiding the creation of a strong political brand. Extending further, the respondents expressed a very favorable perception of the leader and his action orientation. They felt that this perception was augmented by a very favorable comparison vis a vis his predecessor. A respondent, Jack, stated, "There is so much liking for Mr. Modi as he is an extreme opposite to his predecessor. People believe he's doing something” (Male, Bangalore, 28 yrs).

Related to this was another dimension of the voters' perception of the leader in the context of his political party. They stated that the leader seemed to have emerged as almost the sole face of leadership of the BJP. A respondent, Fallon, stated that, "Also, Modi is the only leadership working in the BJP" (Male, Hyderabad, $25 \mathrm{yrs}$ ).

In summary, the study found that the leader's image as perceived by the voters is a super powerful dimension that can even superimpose on the voter's perception of the party and its image. 


\subsubsection{Dynamic and competent leader}

The study has fore grounded the dynamism and competence of NM as a leader. Respondents felt that the dynamism of NM as a leader was possible due to his successful shift of the BJP from its entrenched ideological base. A respondent, Jade stated, "The RSS is their ideological mentor. One of the reasons why Modi has become PM is that because there will be a difference. I mean he's not taking their political beliefs or ambitions forward" (Female, Delhi, 23 yrs).

Further, they also felt that Modi has shown his dynamism by carefully veering clear of controversial issues tarnishing the Party image. A respondent, Nate, stated, "But I will say, add to that, they do not start these kinds of conversations on their own, agreed, very smart move. I'm sure Modi has given them guidelines to back off a little on these topics"(Male, Pune, 26 yrs). Along with the dynamism of Modi, the respondents also positively identified his competence as an almost innovative visionary with regards to building a strong political brand image for himself and his party.

A respondent, Dirk, stated that "I mean it all started with Modi coming on FB and websites saying that if you want to convey a message to me, if you need any help, I will be there" (Male, Hyderabad, 23 yrs). Another advantage of this positive perception is an indirect ascription of the visionary competence of Modi to the party.

A respondent, Lilli, stated, “At that time there was no was almost no party's website that I had come across. Plus it was good to know that there are parties who were communicating with their voters" (Female, Bangalore, $25 \mathrm{yrs}$ ).

This dimension of dynamism and competence has added considerably to the political image of the leader and the party. 


\subsubsection{Systematic and comprehensive usage of social media to develop intimacy}

The study realized that the BJP and its leader used social media very systematically and comprehensively. Respondents opined that the planned and thorough usage of social media by the BJP and its leader was exactly what was needed for an effective message to be delivered to the electorate. A respondent, Frodo said, "BJP posts are quite brief and small. They don't have lengthy content. It's easier and faster to read" (Male, Mumbai, 22 yrs).

The respondents felt that brevity without compromising on the content is very necessary for the communications by political parties. They also perceived that the BJP realized that social media is the point of a paradigmatic shift. They also felt that the early and strategic usage of social media by the BJP allowed them considerable approval from the voters. A respondent, Gandalf, said, "On every video on the BJP website there are 9,000 likes. There are another 2.000 comments. They have realized that social media is the next big thing" (Male, Delhi, 25 yrs).

As a caveat, they stated that the messages would be more effective if Modi were to personally communicate to the voters through social media. A respondent, Amber, said, "Maybe once in a while he (Modi) can put in a personal message. Maybe once in a month. One tweet from him personally" (Female, Mumbai, 26 yrs).

Thus, the respondents felt that the social media usage by the BJP is one of its strengths. The strength is in terms of the likes that the voters actually provided for the posts of the BJP and the brevity of the posts.

In summary, this 'larger than life image' of Modi was aided by the fact that he is seen as a leader who set a progressive tone to the messages of the BJP. Lastly, for the category of perception and associations, the respondents have clearly mentioned about the leader having superimposed on the party. This superimposition was through his dynamic and competent traits and synchronized ideas by optimally utilizing social media. Therefore, the proposition that can be put forward for the influences of political branding is: 
P2: Dynamism, competence and consummate use of social media constitute the check point of the ability to be clear for developing strong political branding

\subsection{Ability of the leader to maintain virtual presence 4.3.1 Engaging Governance}

The study realized that one of the key dimensions in the development of the BJP and its leader's image is that of engaging governance. They defined it in terms of connectedness, a common language that the people could connect to. Across different cities, the respondents mentioned the sharing of information about the work they did as a part of engaging governance. A respondent, Ross, stated, "I think there is more connectedness. Because you feel the party is talking like how we talk. So we now see that Modi for an example, he is also so connected" (Male, Delhi, 26 yrs).

Other respondents stated that if the actual leaders of the party communicated directly with the voters, there would be greater veracity. A respondent, Hetty stated, "If you get posts and updates from other leaders. You wouldn't be so interested. If you get any updates from Modi and Kejriwal, we will want to read them and know more about it", (Female, Delhi, 25 yrs). They also stated that this connectedness led to an increased sense of engaging governance when the party and the leader delivered on their promises.

A respondent, Manning, stated, "The expectations which the voters have. The leaders have to live up to them" (Male, Bangalore, 24 yrs). Thus, it can be seen from the respondents' contribution that the dimension of engaged governance was based on connectedness which was in turn based on the party's and the leader's ability to deliver on their promises. 


\subsubsection{Synchronization of Ideas with Media Usage}

The study found that respondents offered views about synchronization of ideas with media usage by stating the most suitable means that needs to be used by political parties for disseminating their messages. A respondent, Adrian, stated, "Twitter is a place where the news and feeds are more believable. If the P.M. 's handle has some Tweet, it's more of that person tweeting, and reaching out to his audience he caters to (Male, Mumbai, 26yrs)."

Another point that emerged related to clarified perspectives as another constituent of synchronization. Thus, a respondent, Kelly, stated, "If you want a refined view of something you will go to Quora" (Female, Bangalore, 24 yrs). Additionally, synchronization referred to the immediacy of the messages posted by the Party. A respondent, Milos stated, "I've actually visited the BJP website. Yesterday, once every two hours they were putting videos that say BJP for Delhi and they are trending the message of BJP for Delhi every 2 hours (Male, Delhi, 24 yrs)." Moreover, synchronization is associated with the pitching of the party's message. A respondent, Fred stated, "I think one more thought is that strategically they are pitching themselves as a party that means business. No interviews, no extended press conferences because they try to look like a party that's in order" (Male, Mumbai, 27 yrs).

In conclusion, the respondents stated that the messages delivered by the party and leader could be synchronized with the media. This could be achieved by ensuring that they were regularly updated, possessed refined views and delivered messages through media that are themselves credible in the first place. 


\subsubsection{Comprehensive Image of the party and the leader}

The study discovered that the respondents felt quite strongly about the overall image of the BJP as a party and Modi as its leader. They had strong reservations about the BJP's affiliation with right wing fundamentalism. They characterized fundamentalism as 'saffron', the color most associated with right wing Hindu based fundamentalism in India.

Thus, a respondent, Rene stated, "If Modi can move away from his saffron image, it would be great for him and the party” (Female, Pune, $25 \mathrm{yrs}$ ). This view was expressed not only about Modi as the party leader, but it also extended to the BJP as a party. A respondent, Green, stated, "Basically, the image of the BJP is that of a communal party. That is the reason that I feel that I would not support this party because their reforms would be mostly for their people” (Male, Delhi, $26 \mathrm{yrs})$.

Additionally, many responses were more direct about the negative effect of this element of the BJP. A respondent Hector, stated, “Because of the BJP'S Hindutva Lines, we look at it negatively" (Male, 27, Hyderabad). Thus the other advantageous points of the dimensions of the BJP and the leader's mage can be seriously undermined by the apperception of the voters about the BJP and its leader's right wing affiliation. Therefore, the following proposition can be put forward.

P3: Engaging governance and optimal usage of media constitute the check point of the ability to maintain virtual presence for developing strong political branding

4.4 Ability of the leader to communicate performance and results 


\subsubsection{Proof of Performance}

There was a strong point of view that the party leader, NM, specifically needed to deliver on the promises made. The respondents felt that the quantum of promises made and the work done need to be nearly equal. A respondent, Wilma, stated, "I think he should just fulfill the promises he has done. That will do. He will not need to do any communication (Female, Delhi, 24 yrs.)".

Further, respondents also expressed about collaboration and inclusiveness. This inclusiveness extended to supporting other political parties to achieve results. A respondent, Betty, stated, "If Modi supports AAP from the center, AAP can come big in different states. Provided they work and not gripe. You have to get along and do work" (Female, 25, Bangalore).

The respondents also expressed views that were similar in nature with regards to the imperative of showing performance. These views had a tone which cannot be ignored by political parties or political leaders. A respondent, Ciarian stated, "Modi is seen as the person making promises. We look forward to the work he has done and compare it to the promises made” (Male, Delhi, 26 yrs).

In summary, the respondents stated that the BJP and Modi as its leader are measured in terms of the actual work performed. Thus, if the voters feel a sufficient incongruence between the two, they will negatively evaluate the political brand of the BJP and Modi. 


\subsubsection{Strong Leadership}

The presence of strong leadership plays an important role in the creation of an effective brand of the party and the leader. The study also realized an important point about Modi's ubiquity on social media. This aspect is about his being perceived as apotent and strong leader. This strength was represented in terms of honesty and probity, which was further enhanced by a positive comparison with other party leaders.

A respondent, Deen stated, "There is a lot of gap between Modi and the others. Others are mostly seen as corrupt people or power hungry people” (Male, Mumbai, 26 yrs.) This point was further strengthened when the respondents equated NM with the face of the BJP. Respondents stated that his status is like that of a brand in its own right. A respondent, Meethi stated “We have to realize that Modi is a brand. It's almost like he is the face of the party. Like the party is dependent on him" (Female, Delhi, 26 yrs).

The respondents also said that strong dynamic leadership is also seen as a competitive advantage that the BJP enjoys. A respondent, Dillon, stated, "Another reason is that because he is competing against the leaders of the other parties rather than competing against the whole party. It was Narendra Modi against Rahul Gandhi (Male, Bangalore, 25yrs.)

In conclusion, the study realized that the sub dimension of strong leadership was understood by the respondents in specific terms. These terms were the political honesty and probity of NM and his ability to be a contender in his own right against other political parties. 


\subsubsection{Viral impact of the communication to gain a head start}

The respondents felt that this dimension was highly relevant to the programs and initiatives of the BJP. They also lead to greater awareness about the Party and its brand thereof. A respondent, Susan stated, "Swaccha Bharath Abhayan. It created awareness. It's a start" (Female, Pune, $25 \mathrm{yrs}$ ). The programs also represented a commencement of an entire form of awareness which has been started by the BJP. These programs not only resulted in the strengthening of the BJP's brand, but also added considerably to the electoral dynamics at the central level.

A respondent, Mel stated, "Prior to the 2014 elections, social media was not big, but it has now contributed to 30\% of the total votes that the BJP got" (Male, Delhi, $25 \mathrm{yrs).}$ This study understood that among the major national political parties in India, it is the BJP and the AAP that have been referred to as the bellwethers of political branding. A respondent, Levy stated, "BJP and AAP have both got a major push due to social media. They mobilized the mass movement" (Male, Mumbai, $27 \mathrm{yrs}$ ).

This view helped us understand that the BJP would be seen as a party that redefined national level electoral politics. Finally, respondents expect that a political brand needs to be developed by specific means. These means include providing evidence of performance by the leader and the party and strong leadership. The means also include the viral impact of the programs and messages that are based on the proof of actual performance of the party and the leader. Therefore, the proposition that can be developed is:

P4: Performance of the leader and the party, strong leadership and viral impact through different media platforms constitute the, ability to communicate sufficient context for developing strong political branding 


\section{Discussions}

The objective of the research was to develop a framework that could be used by political parties to develop the influences of political branding. Thus, the major contribution of the present study is to attempt to develop a robust and comprehensive framework for political branding.

Thus, these are certain important contributions of this study. First, this framework (Refer Fig. 1) might help facilitate political leaders and parties to involve the voters in a strongly embedded relationship. Second, this framework would help focus on the leader as well as the campaign in terms of political branding.

Third, there are very few studies in the context of the post-election scenario. Fourth, the current investigation might be useful in providing the influences of political branding, which can be used in the pre and post-election scenarios by providing valuable insights to the academicians and the practitioners. Fifth, the study provides a framework that might maximize the dynamism and support of young voters.

The present study attempts to integrate a theory (Norris 2000) and two practitioners' format (Eslinger, 2014) and (Brake 2015). By themselves, these frameworks have been valorized in the fields of mobile marketing and digital leadership respectively. Earlier studies had not discovered that these formats could enrich the domain of political branding.

Further, these formats served as appropriate themes. Additionally, the study provides a framework to political parties and leaders for political branding by extending these formats. In order to so, the framework has four themes: ability to communicate readiness for quick and relevant action, ability to be clear in the expression of the leader's strength, ability of the leader to maintain virtual presence and ability of the leader to communicate performance and results. 


\begin{abstract}
Also, the framework is not a separate treatment of political branding efficacy or political leadership efficiency. This framework might be a complementary study of the both. This complement arise as led to the development of the influences of political branding where the requirements of the voters, the branding exercises of the political party and the leader's efficacy led to our target: strong political branding.
\end{abstract}

The present study has also identified unique findings with regards to political branding. Earlier literature (Marland, 2003) mentioned that the candidate brand of a political party is developed based on the impressions of the citizens. However, the present study found that the political brand of the leader can be different from that of the party.

This change has been observed due to the voters having become more educated. It is further supplemented by the increased awareness of the developments brought in by the leader and the party. Additionally, the personalization and connection effected by the party and the leader with the voter enhances the trustworthiness of the party and the candidate.

Similarly, another study has identified three components of a political brand i.e. policy as service, politician as a tangible service and party as the brand (Henneberg and O'Shaughnessy, 2007). For these elements to be integrated, the political brand needs the placement and synchronization of the abilities of the leader as a paradigmatic operational base.

These were the key and tangible sub elements that enhanced the credibility of the leader and the party. Finally, for developing positive political branding, regular updates and activities are necessary (Zarella, 2010). However, it might be stated that a historical brand might need to be worked upon, the current image might need to be more modern, contemporary, promising and developed from the perceptions and expectations of the current voters.

Finally, our study attempted to develop the practical applications of political branding. However, the framework from the current study can be further solidified by undertaking research in different contexts such as different political parties, voters and other countries. 


\section{Implications and Scope for future research}

The first element of political branding is a generative and personalized mode of empowering the voters. The next stage of our trajectory was the achievement of pracamedic elevation (Posner, 2009). In order to do this, we used the framework of (Brake, 2015), which allowed us to extract key abilities that would be practicable checkpoints to verify the efficacy of the political communication exercise of a party.

Finally, our study is the commencement of an entire academic and practical journey in the Indian context where there have been almost no comprehensive studies of political branding from a praxeological perspective. Thus, we can state that a positive political brand can be developed by a personalized and interactive approach.

The focus of these approaches can be on the welfare of the nation as it enhances the trustworthiness of the party among the citizens. More importantly, this brand is enhanced further by the dynamic, competent, modern, digitally savvy leader. This is because this leader is able to connect easily with the voters. Lastly, political brand approaches can be developed in sync with the voters and their changing thought process. The present study has used a qualitative approach to understand the nuances of political brand.

Future quantitative based studies can be conducted to test the research propositions drafted form this study. This study has extensively focused on one political party of India, i.e. the BJP. Other political parties such as the Congress and AAP can also be studied and compared to understand the political brand.

This study can be seen in terms of the different types of political party systems that could include 2 party systems and multi party systems. This study was undertaken in one emerging country, India. Similar studies can be conducted in other emerging nations with a cross cultural research focus. The present study can be used to develop a political brand image. 
The necessity for the same is that there are almost no studies dedicated to the development of political brand image. Therefore, a standalone project can be undertaken to understand the development of the political brand image. This study was undertaken on external stakes holders, the voters.

Future studies can be undertaken on internal stake holders such as politicians to know more about political brand identity as well. Finally, the political brand image and brand identity of political leaders and parties can be studied effectively in terms of their cultural orientations and varied contexts.

\author{
Insert Table 2 here
}




\section{References}

Axelrod, R. (2000). On Six Advances in Cooperation Theory. Analyse and Kritik (22): 130151.

Baines, P.R. (2005), "Marketing the Political Message: American Influences on British Practices", Journal of Political Marketing: Political campaigns in the New Millennium, 4, 2/3, pp.135-162.

Balmas, M., and Sheafer, T. (2013). Charismatic Leaders and Mediated Personalisation in the International Arena. Communication Research, Vol. XX (X), 1-25.

Banerjee, S., \& Ray Chaudhuri, B. (2016). Factors responsible behind political brand preference: an empirical study on Indian voters. Marketing Intelligence \& Planning, 34(4), 559-582.

Bartle, J. (2001). Labour and liberal democrat relations after 7 June 2001. Representation, 38(3), pp.231-241.

Baumgartner, J.C and J.S. Morris (2010). “ MyFaceTube Politics, Social Networking Web Sites and Political Engagement of Young Adults.” 2010 SAGE Publications 28(1): 24-44.

Bennett, W. (2012). The Personalization of Politics: Political Identity, Social Media, and Changing Patterns of Participation. The ANNALS of the American Academy of Political and Social Science, 644(1), pp.20-39.

Bhatia, T. (2017). Political Parties need to provide accountability. DNA.

Brake, L. (2015). Looking Back. Victorian Periodicals Review, 48(3), pp.312-322.

Busby, R. and Cronshaw, S. (2015). Political Branding: The Tea Party and Its Use of Participation Branding. Journal of Political Marketing, 14(1-2), pp.96-110.

Butler-Kisber, Lynn. (2010). Qualitative Inquiry: Thematic, Narrative and Arts-Informed Perspectives, London: Sage Publications Ltd. 
Booth, D., Cooksey, B., Golooba-Mutebi, F. and Kanyinga, K. (2014). East African Prospects: An Update on the Political Economy of Kenya, Rwanda, Tanzania and Uganda.London: Overseas Development Institute.

Casteltrione, I. (2015). The Internet, social networking Web sites and political participation research: Assumptions and contradictory evidence. First Monday, 20(3).

Chouhan, S. (2014). Facts and figures for India's 2014 general election.http://blogs.reuters.com/india/2014/04/03/facts-and-figures-for-the-2014general-election/India Insight.

Cogburn, D. and Espinoza-Vasquez, F. (2011). From Networked Nominee to Networked Nation: Examining the Impact of Web 2.0 and Social Media on Political Participation andCivic Engagement in the 2008 Obama Campaign. Journal of Political Marketing, 10(1-2), pp.189-213.

Creswell, John .W. (2007), Qualitative Inquiry and Research Design, London: Sage Publications Ltd.

Dazeinfo. (2016). Dazeinfo:: Business News On Smartphone, Social Media, Ecommerce. [online] Available at: http://www.dazeinfo.com [Accessed 6 Dec. 2016].

Dumeresque, D. (2012). The net generation: its impact on the business landscape. Strategic Direction, 28(9).

Eslinger, Tom. (2014). Mobile Magic: The Saatchi and Saatchi Guide to Mobile Marketing and Design. Wiley.

Ewan, Ferlie, Pettigrew, A., Ashburner, L. and Fitzgerald, L. (1997). The new public management in action. Long Range Planning, 30(1), pp.145-146.

FernándezVásquez, R. (2014). Reconfiguracióntopológica para la reducción de pérdidas de energíaen la red de media tensión de la CNFL. RevistaIngeniería, 24(1). 
Fraser, M. and S. Dutta. (2009). Available at: How social media helped Barack Obama to become the most powerful man. Retrieved May 4, 2016, from http://newsblaze.com/ story/20090128105841zzzz.nb/topstory.html.

French, A. and G. Smith. (2010). 'Measuring political brand equity: a consumer oriented approach'. European Journal of Marketing. 44(3-4): 460-477.

Guzmán, F., Paswan, A. and Van Steenburg, E. (2014). Self-Referencing and Political Candidate Brands: A Congruency Perspective. Journal of Political Marketing, 14(1-2), pp.175-199.

Hallin, D. and Mancini, P. (1984). Speaking of the president. Theory and Society, 13(6).

Hamilton, A. and C.J.Tolbert. (2012). "Political engagement and the Internet in the 2008 U.S. Presidential elections: A panel survey," In: Eva Anduiza, Michael J. Jensen, and LaiaJorba (editors). Digital media and political engagement worldwide: A comparative study. Cambridge: Cambridge University Press.

Henneberg, S. and O'shaughnessy, N. (2007). Theory and Concept Development in Political Marketing. Journal of Political Marketing, 6(2-3), pp.5-31.

Hennink, M., I. Hutter, and A. Bailey (2011). Qualitative research methods. London: Sage.

Holt, D. (2002). Why Do Brands Cause Trouble? A Dialectical Theory of Consumer Culture and Branding. Journal of Consumer Research. 29 (1).

Indexmundi.com. (2016). IndexMundi - Country Facts. [online] Available at: http://www.indexmundi.com [Accessed 6 Dec. 2016].

Indian web2, (2016). Indian web2. [online] Available at: http://www.indianweb2.com [Accessed 5 Dec. 2016].

Indiaonlinepages.com. (2016). India Guide - Festivals, Culture, City Guide, Weddings, Population, Indiaonlinepages.com. [online] Available at: http://www.indiaonlinepages.com [Accessed 6 Dec. 2016]. 
Jain, V., Kitchen, P., \& Ganesh, B. (2017). The development of political brand image: A study. In Academy of Marketing Science. Colorado: Springer.

Jain, V., Pich, C., Ganesh, B. E., \& Armannsdottir, G. (2017). Structured Abstract: Comprehending Political Branding and Brand Image of the BJP in India. In Creating Marketing Magic and Innovative Future Marketing Trends (pp. 1307-1313). Springer, Cham.

Jason Howard, (2009). Hope for Appalachia. Appalachian Heritage, 37(3), pp.71-73.

Juris, J. S. (2004). Networked Social Movements: Global Movements for Global Justice, in M. Castells (ed.) The Network Society: A Cross-Cultural Perspective. London: Edward Elgar.

Kamberelis, George, and Greg Dimitriadis. (2013). Focus groups: From structured interviews to collective conversations. New York: Taylor and Francis Group.

Karpf, D. (2012). The MoveOn effect. 1st ed. New York: Oxford University Press.

Kim, W. (2001). The human society and the Internet. 1st ed. Berlin: Springer.

Lees-Marshment, J. (2001). The O'Cass, A. and Voola, R. (2011). Explications of political market .Marketing (14): 129-151.

Marland, A. (2003). Marketing political soap: a political marketing view of selling candidates like soap, of electioneering as a ritual, and of electoral military analogies. Journal of Public Affairs, 3(2), pp.103-115.

Milena, Z.R., G.Dainora, and S.Alin (2008). Qualitative Research Methods: A Comparison between focus-group and in-depth interview. Retrieved from:https://core.ac.uk/download/files/153/6257621.pdf

Milewicz, C. and Milewicz, M. (2014). The Branding of Candidates and Parties: The U.S. News Media and the Legitimization of a New Political Term. Journal of Political Marketing, 13(4), pp.233-263.

Moran, G., Muzellec, L. and Nolan, E. (2014). Consumer Moments of Truth In the Digital Context. Journal of Advertising Research, 54(2), pp.200-204. 
Needham, C. (2006). Brands and political loyalty. Journal of Brand Management, 13(3), pp.178-187.

Negrine, R. (2008). Book Review: Digital Democracy: Issues Of Theory and Practice. Journalism 3 (1): 111-114.

Nielsen, K. (2016). The everyday politics of India's "land wars" in rural eastern India. Focaal, 2016(75).

Norris, Pippa. (2000). A virtuous circle. Cambridge: Cambridge University Press.

O'Shaughnessy, N., Baines, P., O'Cass, A. and Ormrod, R. (2012). Political Marketing Orientation: Confusions, Complications, and Criticisms. Journal of Political Marketing, 11(4), pp.353-366.

Pich, C. and Armannsdottir, G. (2015). Political brand image: an investigation into the operationalisation of the external orientation of David Cameron's Conservative brand. Journal of Marketing Communications, pp.1-18.

Pich, C., Dean, D. and Punjaisri, K. (2014). Political brand identity: An examination of the complexities of Conservative brand and internal market engagement during the $2010 \mathrm{UK}$ General Election campaign. Journal of Marketing Communications, 22(1), pp.100-117.

Posner, P. (2009). The Pracademic: An Agenda for Re-Engaging Practitioners and Academics. Public Budgeting and Finance 29(1).

Rawson, E.A.G. (2007). 'Perceptions of the United States of America: Exploring the political brand of a nation'. Place Branding and Public Diplomacy3(3): 213 -221.

Singh, K. (2015). Creating Your Own Qualitative Research Approach: Selecting, Integrating and Operationalizing Philosophy, Methodology and Methods. Vision: The Journal of Business Perspective, 19(2), pp.132-146.

Speed, R., P. Butler., and N. Collins. (2015). Human Branding in Political Marketing: Applying Contemporary Branding Thought to Political Parties and their Leaders. Journal of Political 
Stanyer, J. (2005). Political Parties, the Internet and the 2005 General Election: From Web Presence to E-Campaigning?.Journal of Marketing Management, 21(9-10), pp.10491065.

Strauss, A. and L. Corbin (1990). Basics of Grounded Theory Methods. Beverly Hills, CA.: Sage.

Sultan, Z., M.Moeinaddini, Z.Asadi-Shekari, and M.Zaly Shah. ( 2015). Understanding THE neighbourhood choice decisions of movers: an analysis of focus group discussions. JurnalTeknologi 76 (14).

Temple, Mick (2010). Political Marketing, Party Behaviour and Political Science, Chapter 18 in J. Lees-Marshment, J. Strömbäck and C. Rudd (eds.), Global Political Marketing. Abingdon: Routledge.

Wyatt, T. H., P. B. Krauskopf, and R. Davidson. 2008. "Using Focus Groups For Program Planning And Evaluation". The Journal Of School Nursing 24 (2): 71-82.

Yin, Robert. K. (2003). Case study research: Design and methods (3rd ed.). Thousand Oaks, CA: Sage.

Zarrella, D. (2010). The social media marketing book. Sebastopol, CA: O'Reilly Media, 
Details of the respondents from 3 cites

\begin{tabular}{|l|l|l|l|l|l|}
\hline City & \multicolumn{2}{|l|}{ Gender } & $\begin{array}{l}\text { Age } \\
\text { (Mean) }\end{array}$ & \multicolumn{2}{l|}{ Education } \\
& Male & Female & & $\begin{array}{l}\text { Bachelor's } \\
\text { Degree }\end{array}$ & $\begin{array}{l}\text { Masters' } \\
\text { Degree }\end{array}$ \\
\hline Mumbai & $70 \%$ & $30 \%$ & 24.75 & $41 \%$ & $59 \%$ \\
\hline Delhi & $57 \%$ & $43 \%$ & 23.27 & $61 \%$ & $39 \%$ \\
\hline Pune & $92 \%$ & $8 \%$ & 26 & $74 \%$ & $26 \%$ \\
\hline Hyderabad & $68.42 \%$ & $31.58 \%$ & 29.6 & $52.63 \%$ & $47.37 \%$ \\
\hline
\end{tabular}


Thematic Analysis

\begin{tabular}{|c|c|c|}
\hline Category & Themes & Sample Codes \\
\hline $\begin{array}{l}\text { Ability to } \\
\text { communicate } \\
\text { readiness for } \\
\text { quick and relevant } \\
\text { actions }\end{array}$ & $\begin{array}{l}\text { Personalization and Connection } \\
\text { Mobility in information dispersal } \\
\text { Interactivity with voters and Reciprocity in terms of } \\
\text { voter needs }\end{array}$ & $\begin{array}{l}\text { Talk about the common man, talk about } \\
\text { the nation, let the leaders speak, use } \\
\text { good governance, two way } \\
\text { communication, let us express views. }\end{array}$ \\
\hline $\begin{array}{l}\text { Ability to be clear } \\
\text { in the expression } \\
\text { of the leader's } \\
\text { strength }\end{array}$ & $\begin{array}{l}\text { Leader superimposing on the party } \\
\text { Dynamic and competent leader } \\
\text { Systematic and comprehensive usage of social media to } \\
\text { develop intimacy }\end{array}$ & $\begin{array}{l}\text { One man army, face of the army, moved } \\
\text { from saffron, does something, Modi } \\
\text { started BJP's social media usage, short } \\
\text { clear messages, Modi should } \\
\text { communicate directly. }\end{array}$ \\
\hline
\end{tabular}




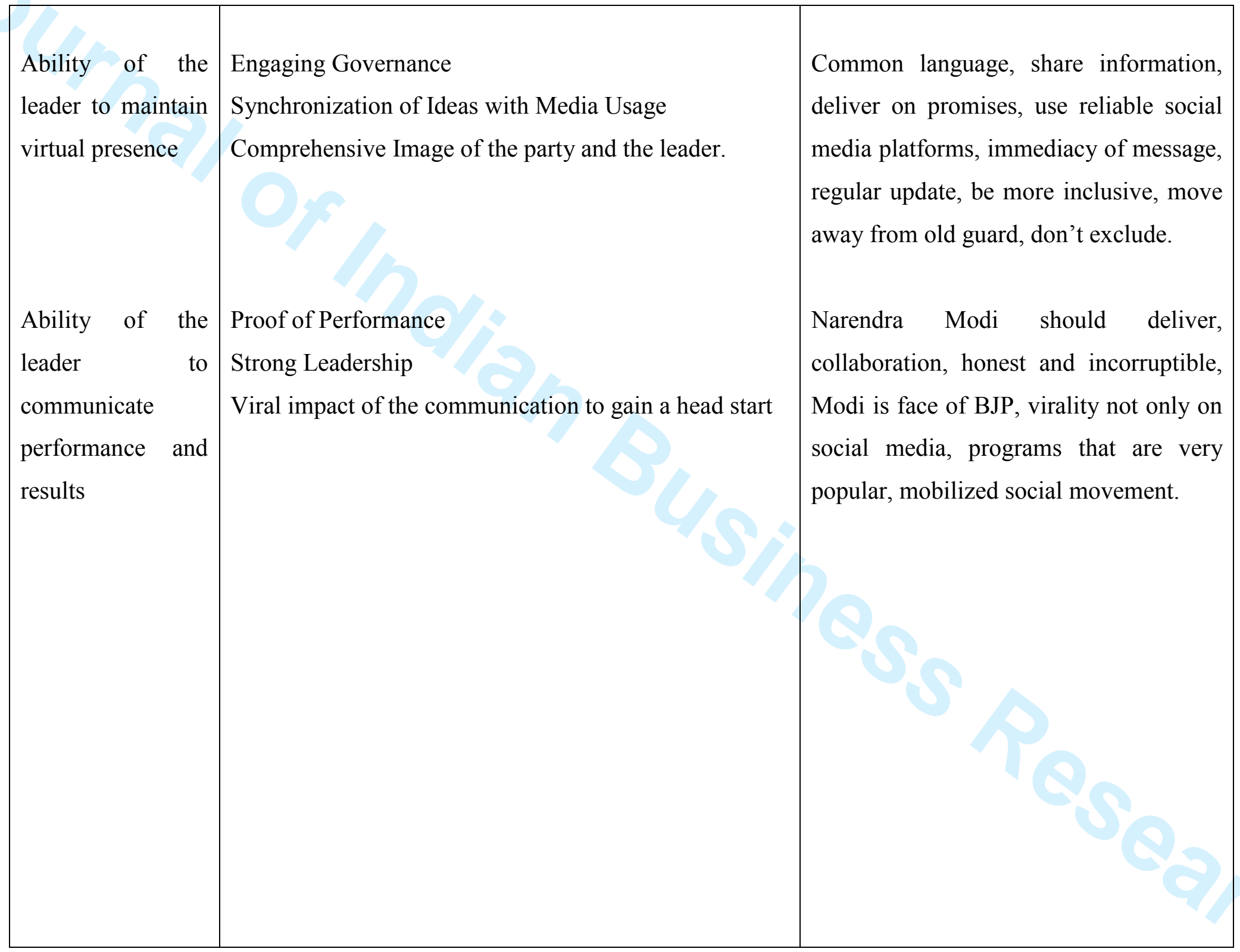


Figure 1: Influences of political branding framework

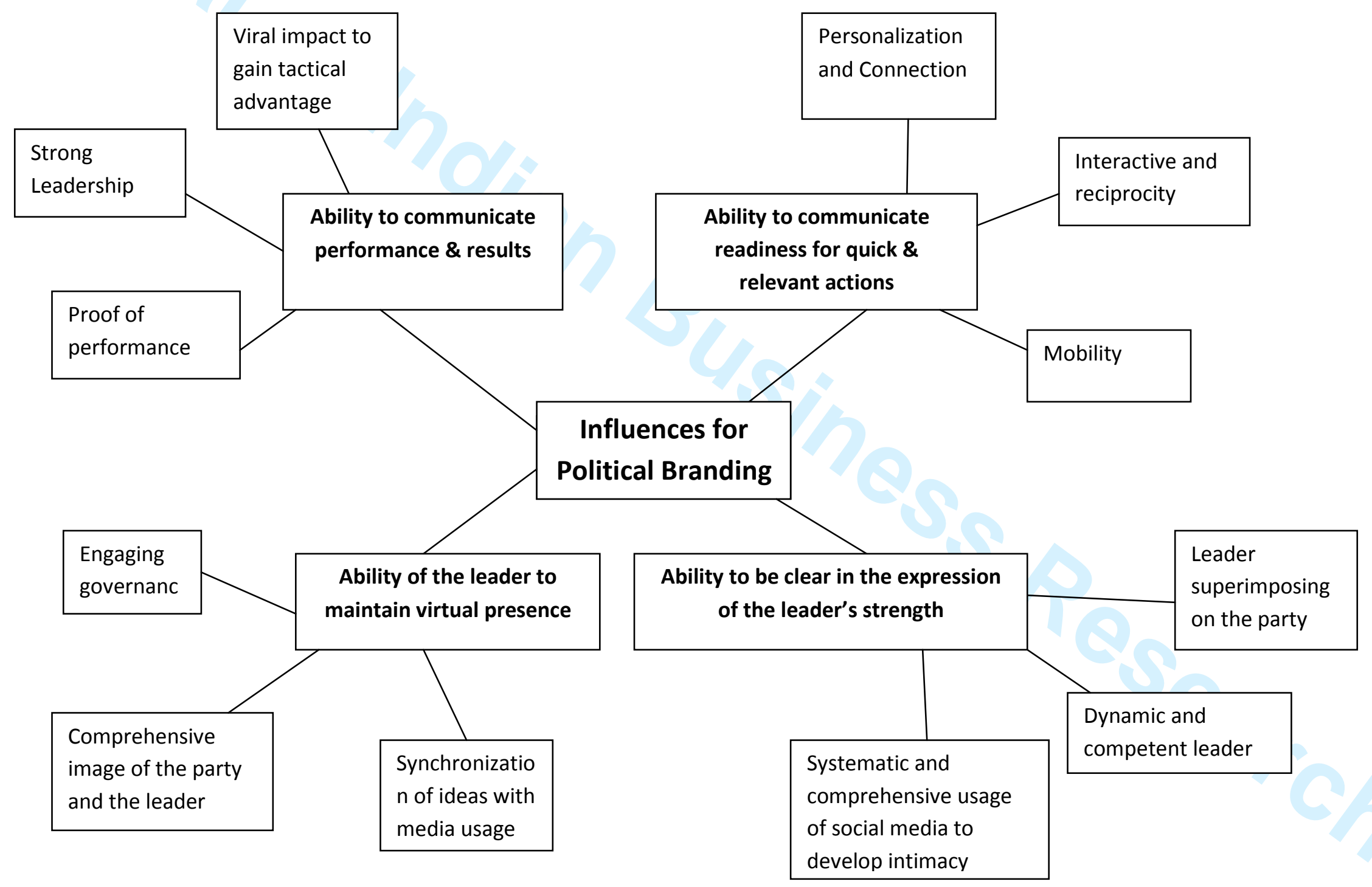


Figure 1: Influences of political branding framework

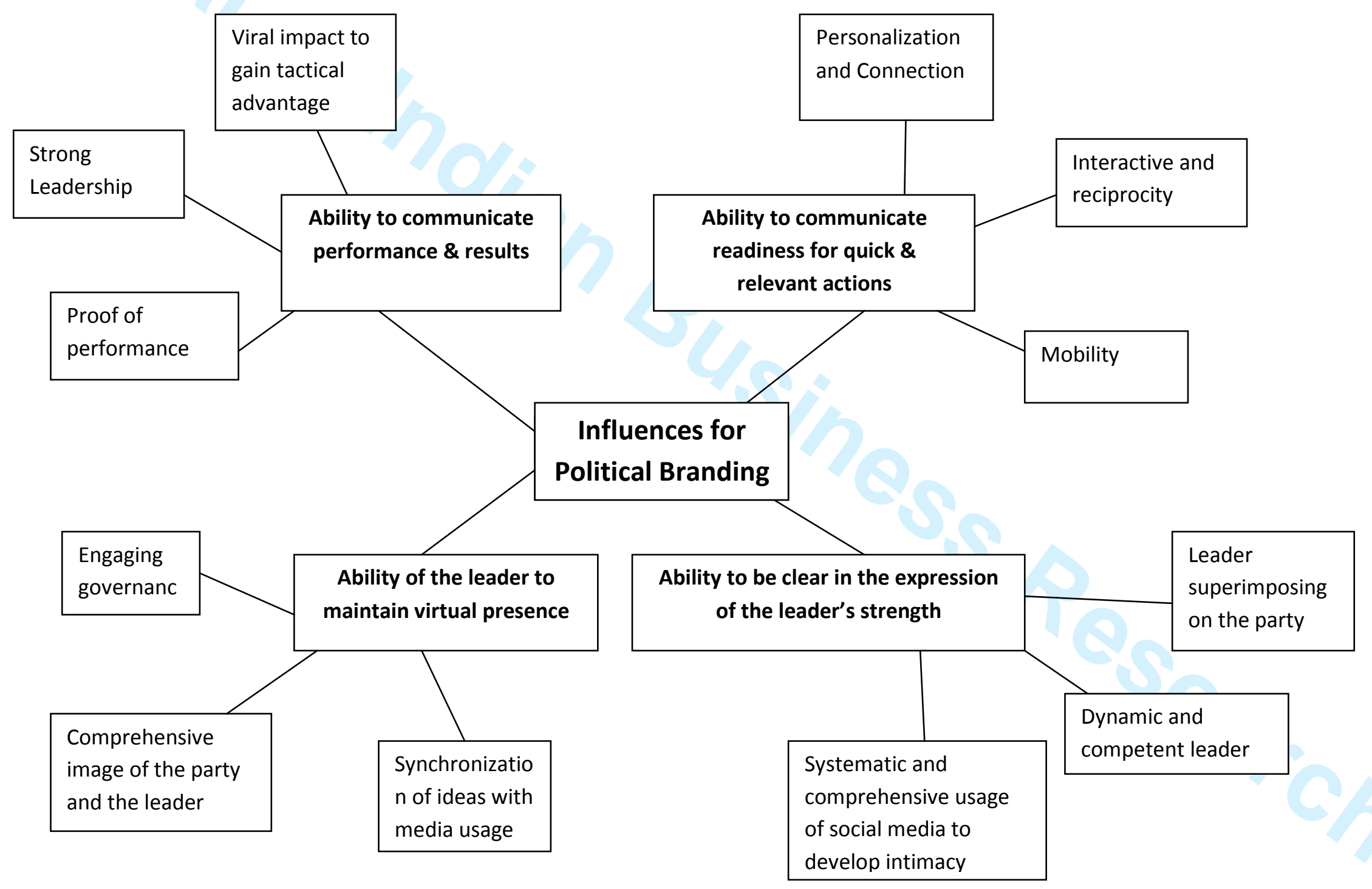




\section{Appendix 1: Focus Group Discussion Guide}

\section{Stage 1: Overall Perceptions about the party and leader (20-25 minutes)}

1. Which are the most serious problems that India faces today?

a. Did you vote for the current prime minister so that these problems may be sorted out?

b. Can 'you explain the reasons in believing that the current prime minister and BJP will be able to solve these problems?

2. What are the best qualities that you believe the Prime Minister and BJP stand for?

a. Why do you associate with those qualities?

b. Why do you think these qualities are what are needed for the country today?

3. What in your view is the weakness that the current Prime Minister and BJP has, if any?

a. Could you explain the reasons for thinking that these weaknesses might prevent the prime minister and BJP from fulfilling their promise?

4. What are your views about the communications approaches and platforms used by BJP and the leader? (Probe: messages)

5. How and with whom do you discuss about BJP and the leader (probe: peers, friends, family)?

6. What is the role of existing political discussions on social media about parties and leaders in Influencing your voting?

\section{Stage 2: Influences of Political Branding (25-30 minutes)}

4. Why do you think the BJP is different from the following parties: a) Congress b) RJD c) AAP?

5. What are your perceptions about the BJP's and the leader's differentiating factors and do you believe it adds to the party's strength?

6. How do you think the BJP had developed from a small party to a party for the people?

7. If you want certain aspects (principles, beliefs, attributes, orientation) of the BJP and the leader to be changed, which aspects should those be? 
8. Why do you think that the programs of the BJP and the leader (like Swach Bharath Abhiyan, Make in India) are representative of the qualities the BJP and the leader stand for?

9. Why do you believe the BJP is the political party for the future of India?

10. How do you believe that the BJP's leadership is capable of producing leaders for the future of the country?

11. Other than the Prime Minister, do you believe there are other leaders who could be a strong Representative of the BJP?

12. What qualities do you think a BJP supporter should possess?

Stage 3: Expectations from the party and the leader for the subsequent election (15-20 minutes)

1. What should BJP and the leader do if you would like to elect them in the next election?

2. What are your expectations from BJP and the leader once they are elected subsequently?

3. What should BJP and the leader not do in the pre-election phase if they wish to be reelected?

4. What should BJP and the leader not do in the post-election phase? 